\title{
Antioxidant effect of angiotensin (1-7) in the protection of pancreatic $\beta$ cell function
}

\author{
FEN ZHANG, CHANG LIU, LEI WANG, XI CAO, YING YING WANG and JIN KUI YANG \\ Department of Endocrinology, Beijing Tongren Hospital, Capital Medical University, Beijing 100730, P.R. China
}

Received March 22, 2015; Accepted March 22, 2016

DOI: $10.3892 / \mathrm{mmr} .2016 .5514$

\begin{abstract}
It is well known that the local renin-angiotensin system (RAS) is activated in the diabetic state, which results in an increase in the level of oxidative stress injury to pancreatic $\beta$ cells. The angiotensin-converting enzyme 2 (ACE2)/angiotensin (1-7) [Ang (1-7)]/Mas axis is a negative regulator of the classical renin-angiotensin system. In order to investigate the antioxidant effect of Ang (1-7) on pancreatic $\beta$ cells, INS-1 cells were cultured and oxidative stress was induced by treatment with $\mathrm{H}_{2} \mathrm{O}_{2}$. Glucose-stimulated insulin secretion (GSIS), the generation of reactive oxygen species (ROS), mitochondrial membrane potential (MMP) and glucose-stimulated calcium (GSCa) responses in $\beta$ cells were determined following treatment with Ang (1-7). It was observed that $\mathrm{H}_{2} \mathrm{O}_{2}$ significantly impaired the insulin secreting function, increased the production of ROS, and also decreased the levels of GSCa and MMP. Pre-treatment with Ang (1-7) alleviated these effects and treatment with A779 [antagonist of Ang (1-7)] prevented the effects of Ang (1-7). Based on these findings, it was concluded that Ang (1-7) can protect pancreatic $\beta$ cells from oxidative injury and such protection can be blocked by its antagonist A779.
\end{abstract}

\section{Introduction}

Diabetes is a chronic metabolic syndrome caused by insulin deficiency and resistance. There are 200 million diabetic individuals in the world, with only approximately one-half being diagnosed, and these numbers are expected to double by 2030 . The disease often results in long-term microvascular, neurological, and macrovascular complications, including retinopathy, nephropathy, neuropathy, and increased risk of cardiovascular disease. Excessive activation of angiotensin II (AngII) is an important underlying mechanism for the development of diabetes, and Ang (1-7)

Correspondence to: Professor Jin Kui Yang, Department of Endocrinology, Beijing Tongren Hospital, Capital Medical University, 1 Dongjiaomin Alley, Beijing 100730, P.R. China

E-mail: jinkui.yang@gmail.com

Key words: angiotensin-(1-7), oxidative stress, renin-angiotensin system, angiotensin-converting enzyme 2 , pancreatic $\beta$ cell is hypothesized to counteract it. Furthermore, the reninangiotensin system (RAS) is significantly involved in the development of diabetes and its complications. The activation of RAS causes pancreatic $\beta$ cell dysfunction by suppressing pro-insulin biosynthesis, glucose-stimulated insulin secretion (GSIS) and first phase insulin secretion (1-2), as well as by increasing islet fibrosis (3) and oxidative stress (4). The angiotensin-converting enzyme 2 (ACE2)-angiotensin (1-7) [Ang (1-7)]-Mas axis is suggested to have an antagonistic effect on the RAS, while Ang (1-7) is the main antagonist of AngII. Angiotensin-converting enzyme inhibitor (ACEI) and angiotensin receptor antagonist (ARB) can alleviate these pathological changes $(3,5-7)$. Also, several clinical experiments have demonstrated the effectiveness of RAS blockade in reducing the onset of diabetes (8-11).

In 2006, it was demonstrated that patients with Severe Acute Respiratory Syndrome (SARS) were more inclined to exhibit higher blood glucose (12), and this may be partly due to the fact that ACE2 is a functional receptor for the SARS coronavirus (13). Thus we hypothesized that the ACE2-Ang (1-7)-Mas axis has a protective effect on pancreatic $\beta$ cell function. Our previous study demonstrated for the first time that loss of ACE2 led to impaired glucose homeostasis in mice. In addition, ACE2 knockout (ACE2-/y) mice exhibit progressive impairments in glucose tolerance and reduced first-phase insulin secretion (14). The present study aimed to investigate the underlying molecular mechanisms of these effects. Accordingly, ACE2 gene therapy improved glycemic control in diabetic mice via Ang (1-7) (15). Ang (1-7) is hypothesized to exhibit antioxidant effects in diabetic nephropathy, hypertension, cardiovascular diseases and in the brain (16-19). These data confirm the protective role of the ACE2-Ang (1-7)-Mas axis in the pancreas and establish a novel target for the treatment of type 2 diabetes mellitus.

Oxidative stress is one of the most important factors in $\beta$ cell loss (20). However, little is known regarding the correlation between Ang (1-7) and oxidative stress in the pancreas. In the present study, the protective effect of Ang (1-7) on oxidative $\beta$ cell damage was investigated. The protective effect was shown to occur by improving GSIS, glucose stimulated calcium (GSCa) responses and the mitochondrial membrane potential (MMP), which was demonstrated previously (21), and reducing the production of reactive oxygen species (ROS). The selective receptor antagonist A779 was used to confirm the protective role of Ang (1-7). 


\section{Materials and methods}

Cell culture. INS-1 insulinoma cells were a gift from Professor Liu Yong (Shanghai Institutes for Biological Science, Chinese Academy of Sciences, Shanghai, China), which were originally supplied by Dr Claes Wollheim, University Medical Center (Geneva, Switzerland). The culture medium consisted of RPMI-1640 (Hyclone, Logan, UT, USA) with $11.1 \mathrm{mmol} / \mathrm{l}$ D-glucose supplemented with $10 \%$ fetal bovine serum (Hyclone), $100 \mathrm{U} / \mathrm{ml}$ penicillin, $100 \mu \mathrm{g} / \mathrm{ml}$ streptomycin (both from Invitrogen; Thermo Fisher Technology, Inc., Waltham, MA, USA), $10 \mathrm{mmol} / 1 \mathrm{HEPES}, 2 \mathrm{mmol} / 1 \mathrm{~L}$-glutamine, $1 \mathrm{mmol} / 1$ sodium pyruvate and $50 \mu \mathrm{mol} / 1$ mercaptoethanol, in $5 \% \mathrm{CO}_{2}$ at $37^{\circ} \mathrm{C}$.

Oxidative stress model. INS-1 cells were incubated with 0 , $50,100,150,250,300$, and $350 \mu \mathrm{M} \mathrm{H}_{2} \mathrm{O}_{2}$ for $15 \mathrm{~min}$ and cell viability was evaluated using the 3-(4,5)-dimethylthiahiazo (-z-y1)-3,5-di-phenytetrazoliumromide test (Beyotime Institute of Biotechnology, Beijing, China). INS-1 cell viability decreased in a dose-dependent manner following $\mathrm{H}_{2} \mathrm{O}_{2}$ stimulation. The INS-1 cell vitality was reduced to $\sim 70 \%$ with the stimulation of $250 \mu \mathrm{M} \mathrm{H}_{2} \mathrm{O}_{2}$ for $15 \mathrm{~min}$. Thus, oxidative stress was induced by treatment with $250 \mu \mathrm{M} \mathrm{H}_{2} \mathrm{O}_{2}$ for 15 min for the experiments in the present study.

Insulin secretion stimulated by $\mathrm{H}_{2} \mathrm{O}_{2}$. GSIS was measured in INS-1 cells, which were grown for 2 days in 96-well plates, balanced in Krebs-Ringer Bicarbonate Buffer (KRBB) $\left[129 \mathrm{mM} \mathrm{NaCl} ; 4.7 \mathrm{mM} \mathrm{KCl} ; 1.2 \mathrm{mM} \mathrm{KH}_{2} \mathrm{PO}_{4} ; 1.2 \mathrm{mM}\right.$ $\mathrm{MgSO}_{4} ; 2.5 \mathrm{mM} \mathrm{CaCl} 2 ; 5 \mathrm{mM} \mathrm{NaHCO} ;, 10 \mathrm{mM}$ HEPES (Sigma-Aldrich, St. Louis, MO, USA); and $0.1 \%$ bovine serum albumin (Sigma-Aldrich; pH 7.4)] containing $3.3 \mathrm{mM}$ glucose for $1 \mathrm{~h}$, and were then incubated in 3.3 and $16.7 \mathrm{mM}$ glucose $\mathrm{KRBB}$, respectively, at $37^{\circ} \mathrm{C}$ for $2 \mathrm{~h}$.

To determine the effect of $\mathrm{H}_{2} \mathrm{O}_{2}$, INS- 1 cells were grown for $48 \mathrm{~h}$ and subsequently incubated under basal conditions or in the presence of either $10^{-8} \mathrm{~mol} / \mathrm{l}$ Ang (1-7) (Sigma-Aldrich), $10^{-6}$ mol/l A779 (Sigma-Aldrich) or Ang (1-7) and A779 together, for $2 \mathrm{~h} . \mathrm{H}_{2} \mathrm{O}_{2}$ at a final concentration of $250 \mu \mathrm{M}$ was added in the final $15 \mathrm{~min}$. Untreated cells served as a control. The cell supernatant was rapidly removed and rinsed twice with phosphate-buffered saline (PBS; Hyclone). Insulin secretion was determined at $16.7 \mathrm{mM}$ glucose KRBB and insulin levels were measured using an insulin enzyme-linked immunosorbent assay kit (EMD Millipore, Billerica, MA, USA).

Intracellular $\mathrm{Ca}^{2+}$ measurement. INS-1 cells were loaded with $5 \mu \mathrm{mol} / 1$ Fluo-3AM (Biotium, Hayward, CA, USA) in a 40-min incubation at $37^{\circ} \mathrm{C}$ in $3.3 \mathrm{mmol} / \mathrm{KRBB}$ following pretreatment with Ang (1-7) or A779 for $2 \mathrm{~h}$ and then, in the last $15 \mathrm{~min}, \mathrm{H}_{2} \mathrm{O}_{2}$ was added at a $250-\mu \mathrm{M}$ concentration. Cellular $\mathrm{Ca}^{2+}$ signaling was determined with confocal microscopy (Leica TCS SP5; Leica Microsystems $\mathrm{GmbH}$, Wetzlar, Germany). Images were collected using $488 \mathrm{~nm}$ excitation (em) and the emission (em) was determined at $>505 \mathrm{~nm}$.

ROS determination. INS-1 cells were grown in RPMI-1640 in 6-well plates for $48 \mathrm{~h}$, followed by incubation with Ang (1-7) or A779 for $2 \mathrm{~h}$, then a concentration of $250 \mu \mathrm{M} \mathrm{H}_{2} \mathrm{O}_{2}$ was

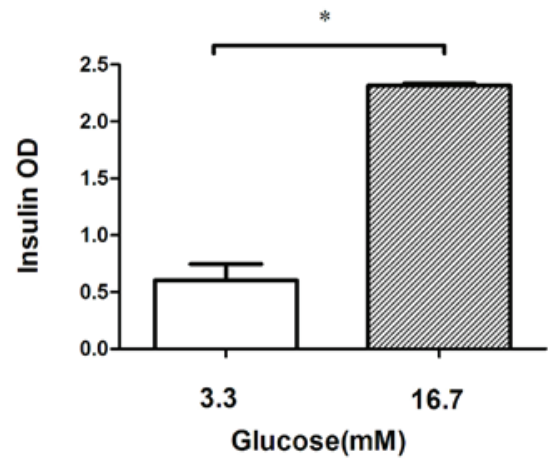

Figure 1. GSIS of INS-1 cells was tested at 3.3 and $16.7 \mathrm{mM}$ glucose. At the higher glucose concentration, the insulin release index of the INS-1 cells was 2.9 , demonstrating healthy INS -1 cell function and glucose sensitivity. ${ }^{*} \mathrm{P}<0.05$. GSIS, glucose-stimulated insulin secretion; OD, optical density.

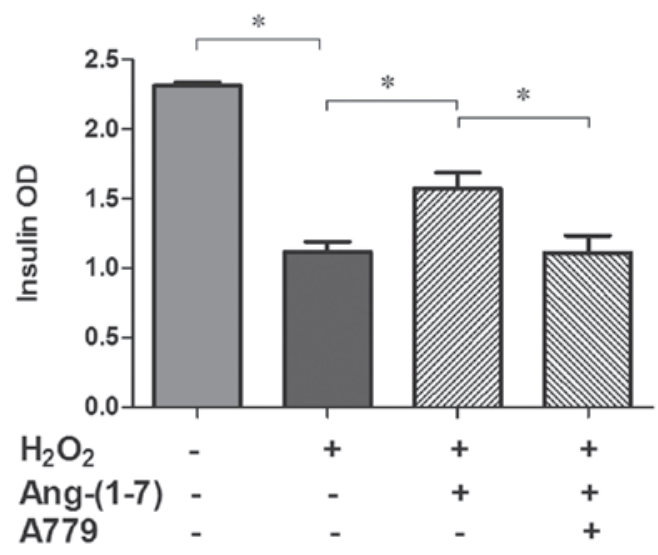

Figure 2. Effects of Ang (1-7) $\left(10^{-8} \mathrm{~mol} / \mathrm{l}\right)$ and A779 $\left(10^{-6} \mathrm{~mol} / \mathrm{l}\right)$ on the GSIS from INS-1 cells in the presence of $\mathrm{H}_{2} \mathrm{O}_{2}$. Insulin secretion was markedly reduced $(51.8 \%)$ by $\mathrm{H}_{2} \mathrm{O}_{2}$ treatment which was partly reversed by Ang (1-7) $(34.1 \%) .{ }^{*} \mathrm{P}<0.05$. Data are presented as the mean \pm standard error of the mean $(n=3)$. Ang (1-7), angiotensin (1-7); GSIS, glucose-stimulated insulin secretion; OD, optical density.

added in the last $15 \mathrm{~min}$. Cells were loaded with $5 \mu \mathrm{mol} / 1$ dihydroethidium (DHE) ROS (Vigorous Biotechnology Co., Ltd.; Beijing, China) detection and suspended in PBS for $20 \mathrm{~min}$ at $37^{\circ} \mathrm{C}$ in the dark. The cells were rinsed twice in PBS and collected with $0.05 \%$ trypsin (Hyclone; GE Healthcare Life Sciences, Logan, UT, USA). Following centrifugation at $140 \mathrm{xg}$ for $5 \mathrm{~min}$, pellets were resuspended in $500 \mu \mathrm{l}$ PBS. ROS was determined using intracellular ROS capture DHE with flow cytometry (BD FACSCalibur; BD Biosciences, Franklin Lakes, NJ, USA). Briefly, an ex wavelength of 480-535 nm was used to determine em $>590-610 \mathrm{~nm}$. Cells were then divided into two subgroups: ROS-negative cells, which exhibit a very low fluorescence intensity and ROS-positive cells, which emit red fluorescence. Ten-thousand events per sample were collected.

MMP. MMP was assessed using JC-1 (Beyotime Institute of Biotechnology) in INS-1 cells. Cells grown in 6-well plates were incubated with $1 \mathrm{ml} \mathrm{JC}-1(2 \mathrm{mg} / \mathrm{ml})$ for $20 \mathrm{~min}$ at $37^{\circ} \mathrm{C}$. The cells were centrifuged at $1,000 \mathrm{x}$ g for $5 \mathrm{~min}$, while the pellets were resuspended in $500 \mu 1$ PBS. Carbonyl cyanide M-chlorophenylhydrazone (CCCP; Beyotime Institute of Biotechnology), a mitochondrial electron transport chain 
$\mathbf{A}$
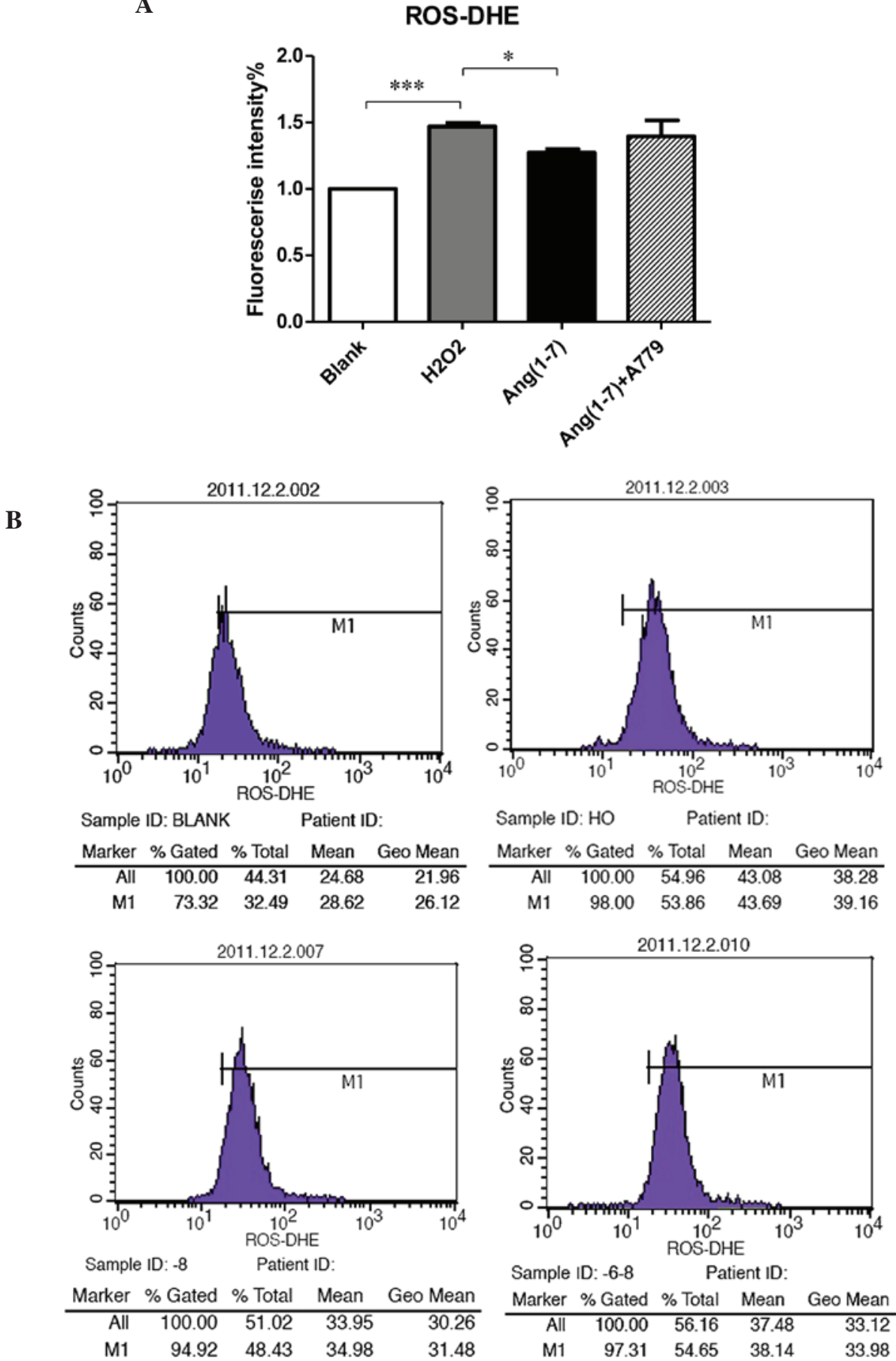

Figure 3. Effect of Ang (1-7) and A779 on the generation of ROS stimulated by $\mathrm{H}_{2} \mathrm{O}_{2}$. (A) Effects of Ang (1-7) (10-8 mol/1) and A779 (10-6 mol/l) on the glucose ( $16.7 \mathrm{mmol} / \mathrm{l}$ )-stimulated insulin release from INS-1 cells in the presence of $\mathrm{H}_{2} \mathrm{O}_{2}$. ROS levels were elevated markedly $(46.8 \%)$ following $\mathrm{H}_{2} \mathrm{O}_{2}$ treatment which was partly reversed by Ang (1-7) (27.1\%). This effect was blocked by A779. (B) The effect of Ang (1-7) and A779 on the generation of ROS stimulated by $\mathrm{H}_{2} \mathrm{O}_{2}$ was tested by flow cytometry. ${ }^{*} \mathrm{P}<0.05 ;{ }^{* * * *} \mathrm{P}<0.001$. Data are presented as the mean \pm standard error of the mean $(\mathrm{n}=3)$. Ang (1-7), angiotensin (1-7); ROS, reactive oxygen species; DHE, dihydroethidium.

inhibitor, served as a positive control. CCCP $(10 \mathrm{M})$ was added to the cells for $20 \mathrm{~min}$. In total, 10,000 cells from each well were analyzed by flow cytometry (ex, $490 \mathrm{~nm}$, em, $590 \mathrm{~nm}$ ). Color change from green to red indicated an increase in the MMP or the improvement of mitochondrial function.

Statistical analysis. Statistical analyses were performed using GraphPad Prism 5 (http://www.graphpad.com/), and data are expressed as means \pm standard error of the mean. One-way analysis of variance followed by Tukey's or Dunnett's tests were used to compare all groups or selected groups to the control and $\mathrm{P}<0.05$ was considered to indicate a statistically significant difference.

\section{Results}

Insulin release. The quantity of insulin released from the INS-1 cells was significantly increased, as expected, when 
A

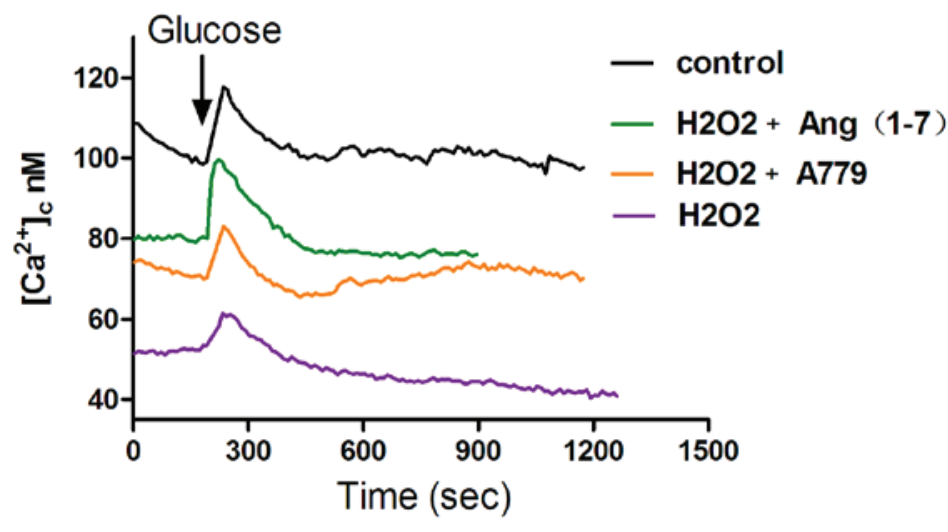

B

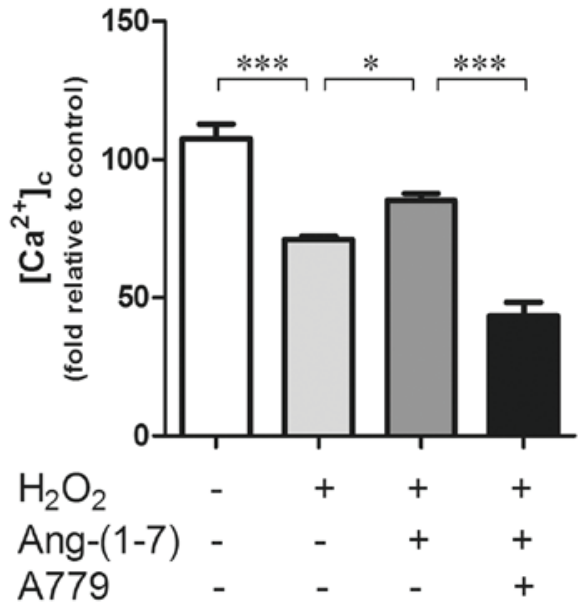

Figure 4. Ang (1-7) restores glucose-stimulated calcium in the presence of $\mathrm{H}_{2} \mathrm{O}_{2}$. (A) $\mathrm{H}_{2} \mathrm{O}_{2}$ clearly decreased the calcium fluorescence intensity when compared with the control groups. Pre-treatment with $10^{-8} \mathrm{~mol} / 1$ Ang (1-7) for $2 \mathrm{~h}$ prior to adding $\mathrm{H}_{2} \mathrm{O}_{2}$ upregulates calcium fluorescence significantly, and treatment with A779 $\left(10^{-8} \mathrm{~mol} / 1\right.$ for $\left.2 \mathrm{~h}\right)$ can selectively inhibit this effect. Ang (1-7) restored the amplitude of calcium (first phase of insulin secretion) in the presence of $\mathrm{H}_{2} \mathrm{O}_{2}$. (B) Graph of calcium fluorescence intensity. Pre-treatment with $10^{-8} \mathrm{~mol} / 1 \mathrm{Ang}$ (1-7) for $2 \mathrm{~h}$ prior to adding $\mathrm{H}_{2} \mathrm{O}_{2}$ upregulates calcium fluorescence by $25 \%(\mathrm{P}<0.05)$, and $\mathrm{A} 779\left(10^{-8} \mathrm{~mol} / \mathrm{l}\right.$ for $\left.2 \mathrm{~h}\right)$ can selectively inhibit this effect $(\mathrm{P}<0.05) .{ }^{*} \mathrm{P}<0.05$ and ${ }^{* * *} \mathrm{P}<0.001$. Data are presented as the mean \pm standard error of the mean $(n=3)$. Ang (1-7), angiotensin (1-7).

the glucose concentration in the incubation medium was increased from 3.3 to $16.7 \mathrm{mmol} / \mathrm{l}$ (Fig. 1).

Ang (1-7) restored GSIS in the presence of $\mathrm{H}_{2} \mathrm{O}_{2}$. Groups treated with $\mathrm{H}_{2} \mathrm{O}_{2}$ exhibited significantly impaired insulin secretion (51.8\%) compared with the control groups. Pre-treatment with $10^{-8} \mathrm{~mol} / 1 \mathrm{Ang}$ (1-7) prior to the addition of $\mathrm{H}_{2} \mathrm{O}_{2}$ can restore insulin secretion significantly, although not to basal levels $(26.1 \% ; \mathrm{P}<0.05)$, and its antagonist $\mathrm{A} 779$ can inhibit this restorative effect $(\mathrm{P}<0.05$; Fig. 2).

Generation of intracellular ROS. To determine the potential antioxidant role of Ang (1-7) in pancreatic $\beta$ cells, INS- 1 cells were used to measure the level of ROS. As shown in Fig. 3, adding $250 \mu \mathrm{mol} / 1 \mathrm{H}_{2} \mathrm{O}_{2}$ for $15 \mathrm{~min}$ to the INS-1 cells clearly increased the production of ROS compared with the control groups at $16.7 \mathrm{mM}$ glucose. Pre-treatment with $10^{-8} \mathrm{~mol} / \mathrm{l}$ Ang (1-7) for $2 \mathrm{~h}$ prior to adding $\mathrm{H}_{2} \mathrm{O}_{2}$ reduced the level of ROS $(\mathrm{P}<0.05)$, while treatment with $10^{-8} \mathrm{~mol} / \mathrm{l}$ for $2 \mathrm{~h} \mathrm{A779}$ selectively inhibited this effect (Fig. 3).

Intracellular $\mathrm{Ca}^{2+}$ imaging of GSCa. GSCa responses are one of the most commonly used indexes of $\beta$ cell function. They can provide real-time results of $\beta$ cell function. As shown in Fig. 4, GSCa signaling in INS-1 cells consists of three phases: Phase 0 , the initial dip below baseline due to calcium uptake by the endoplasmic reticulum; phase 1 , the rapid rise to peak calcium level concomitant with the release of pre-docked insulin granules; and phase 2, the elevated plateau. Addition of $250 \mu \mathrm{mol} / 1 \mathrm{H}_{2} \mathrm{O}_{2}$ for $15 \mathrm{~min}$ to INS-1 cells decreased the fluorescence intensity compared with the control group. Pre-treatment with a $10^{-8} \mathrm{~mol} / \mathrm{l}$ Ang (1-7) for $2 \mathrm{~h}$ prior to adding $\mathrm{H}_{2} \mathrm{O}_{2}$ upregulated calcium fluorescence by $25 \%$, and A779 can selectively inhibited this effect. Furthermore, pre-incubation with Ang (1-7) restored the amplitude of calcium in phase 1 and A779 blocked this effect (Fig. 4).
Ang (1-7) restores mitochondrial function in the presence of $\mathrm{H}_{2} \mathrm{O}_{2}$. JC-1 was used to detect the MMP to evaluate the potential antioxidant effect of Ang (1-7) on mitochondrial function in INS-1 cells. Analysis of fluorescence intensity by flow cytometry revealed a significant increase in MMP in Ang (1-7)-treated INS-1 cells (Fig. 5A), which was inhibited by treatment with A779. Furthermore, the red fluorescence, which indicates greater MMP, increased significantly following the addition of Ang (1-7), which was blocked by A779 treatment, as demonstrated by a significant increase in green fluorescence (Fig. 5B). As shown in Fig. 5, INS-1 cells treated with $250 \mu \mathrm{mol} / 1 \mathrm{H}_{2} \mathrm{O}_{2}$ for $15 \mathrm{~min}$ exhibited a decrease in the level of MMP caused by CCCP compared with that in the controls at $16.7 \mathrm{mM}$ glucose. Pre-treatment with a $10^{-8} \mathrm{~mol} / \mathrm{l}$ Ang (1-7) for $2 \mathrm{~h}$ prior to adding $\mathrm{H}_{2} \mathrm{O}_{2}$ increased the level of MMP significantly. Treatment with $10^{-8} \mathrm{~mol} / 1 \mathrm{~A} 779$ for $2 \mathrm{~h}$ inhibited this effect.

\section{Discussion}

The present study demonstrated that Ang (1-7) can partially restore insulin secretion from INS-1 cells (which is reduced by oxidative stress injury) and reduce the level of intracellular ROS. This protective effect was associated with the change in cellular calcium signaling and mitochondrial function. Ang (1-7) can restore early phase calcium signaling and mitochondrial membrane potential, and has a protective effect on mitochondrial function; however, Ang-(1-7) protective effects could be blockaded by its specific inhibitor, A779. To the best of our knowledge, this is the first study to confirm the antioxidant effect of Ang (1-7) in INS-1 $\beta$ cells.

Oxidative stress results in an increase in the production of ROS and a reduction of the scavenging mechanisms. It has been well-documented that ROS exhibits an important role in the development of diabetes. As the end products of oxidative stress, a certain level of ROS is required for glucose homeostasis (22). However, excess ROS leads to $\beta$ cell dysfunction 
A

Ins-1 JC-1
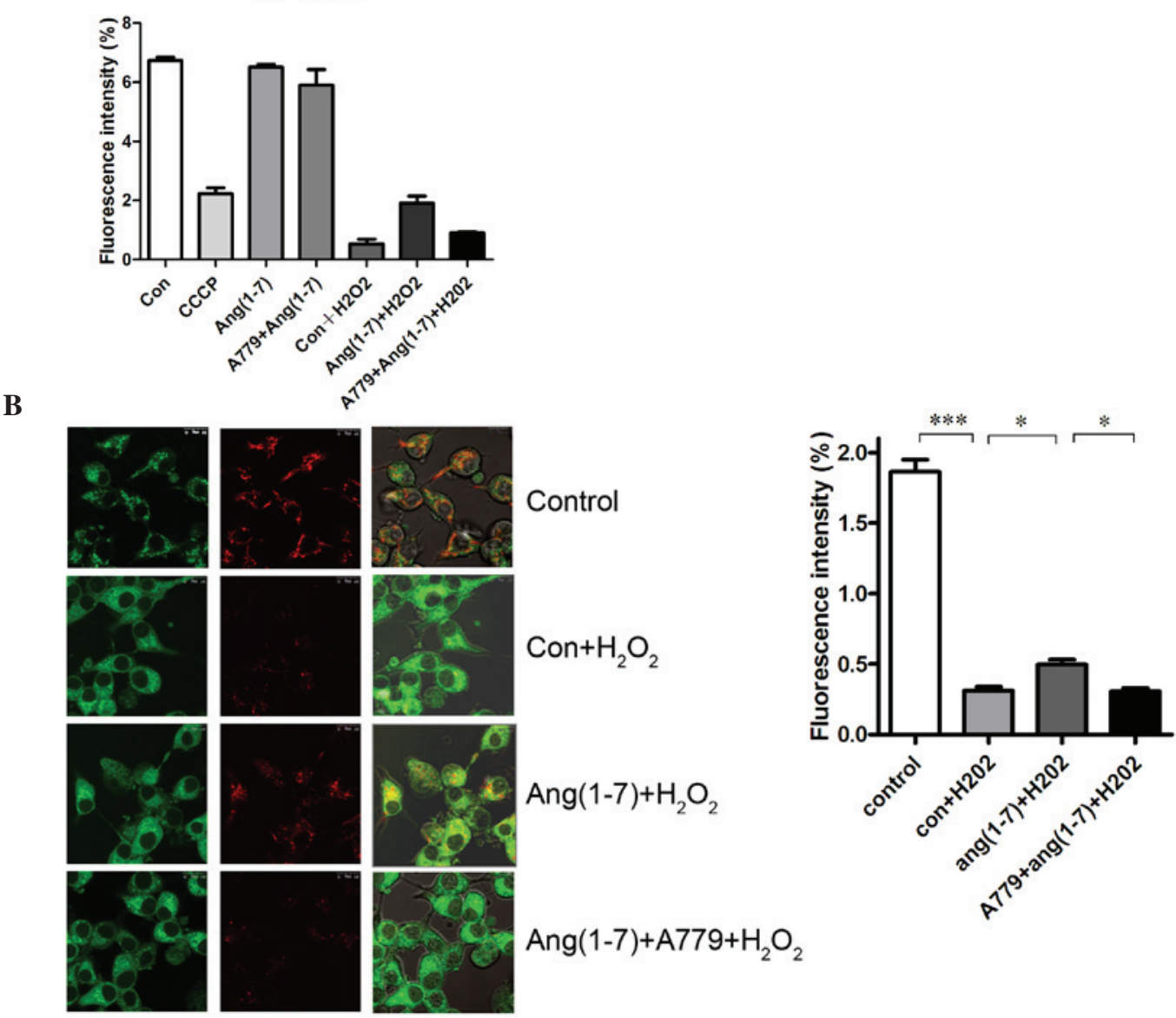

Figure 5. Ang (1-7) restored the MMP in the presence of $\mathrm{H}_{2} \mathrm{O}_{2}$. (A) Flow cytometry using JC-1 in INS-1 cells. (B) JC-1 staining in INS-1 cells. MMP was evaluated by laser confocal microscopy. Ang (1-7) decreased the green fluorescence (column 1) and increased the red fluorescence (column 2) when compared with the Con $+\mathrm{H}_{2} \mathrm{O}_{2}$ groups. Ang (1-7) restores MMP in the presence of $\mathrm{H}_{2} \mathrm{O}_{2}$. The staining was quantified and presented as a graph. Ang (1-7) treatment reversed the decreases in the MMP induced by $\mathrm{H}_{2} \mathrm{O}_{2}\left(15 \mathrm{~min}\right.$ at $\left.250 \mu \mathrm{M} \mathrm{H}_{2} \mathrm{O}_{2}\right)$, and this effect was blocked by $\mathrm{A} 779 .{ }^{*} \mathrm{P}<0.05$ and ${ }^{* * *} \mathrm{P}<0.001$. Data are presented as means \pm standard error of the mean $(n=3)$. MMP, mitochondrial membrane potential; Con, control.

by promoting $\beta$ cell apoptosis and inactivating genes involved in insulin synthesis, such as v-maf avian musculoaponeurotic fibrosarcoma oncogene homolog $\mathrm{A}$ and pancreatic and duodenal homeobox 1 (23). In addition, hyperactivity of RAS leads to the development of $\beta$ cell dysfunction by increasing oxidative stress and fibrosis (3-4). Ang (1-7) is considered to be an important antagonist of AngII and it has been shown to be able to reduce oxidative stress in the kidneys, cardiovascular system and neural system; however, the effects of Ang (1-7) in pancreatic $\beta$ cell remains unknown.

We hypothesized that the effects of Ang (1-7) occur via the same mechanisms in pancreatic $\beta$ cells. As shown in the present study, Ang (1-7) reduced the intracellular ROS levels in INS-1 cells and had a protective effect on $\beta$ cell function. Bindom et al (15) found that ACE2 overexpression in the pancreas of diabetic rats improves the function of $\beta$ cells. Furthermore, the protective effect can be blocked by its specific inhibitor A779, which suggested that this effect was mediated by Ang (1-7) (15) and is consistent with the findings of the present study. In addition, chronic injection of Ang (1-7) improves insulin sensitivity in rats with a high-fructose diet (24), Mas receptor knockout mice exhibited decreased insulin sensitivity, impaired glucose tolerance and glucose uptake (25). These studies demonstrated the protective role of Ang (1-7) in the development of diabetes and metabolic syndrome. In addition, a number of studies in other systems supported the idea that the protective role of Ang (1-7) occurs by reducing oxidative stress. ACE2 overexpression results in a reduction of ROS formation in the brain (17). Furthermore, continuous intravenous infusion of Ang (1-7) restores vasodilation and protects the myocardium via inhibition of oxidative stress (24).

In pancreatic $\beta$ cells, the regulation of intracellular calcium is crucial to the processes of insulin secretion (26); thus, analyzing GSCa responses can provide information regarding the viability and function of pancreatic $\beta$ cells. GSCa results can be obtained rapidly and at a lower cost than GSIS (27). In addition, the calcium curve directly reflects the changes in insulin secretion within the first 15 min following the addition of glucose. In the present study, it was observed that the intracellular calcium fluorescence intensity and the amplitude of insulin secretion in the first phase significantly decreased following treatment with $\mathrm{H}_{2} \mathrm{O}_{2}$. This result is consistent with the insulin secretion experiment, which suggests that the reduction of insulin secretion is correlated with a decrease in intracellular calcium. Ang (1-7) can restore the calcium 
fluorescent intensity and the signaling peak of first phase insulin secretion. Moreover, A779 can block this effect. This study confirmed that oxidative stress can cause a decline in intracellular calcium, which results in the reduction of first phase insulin secretion in pancreatic cells, and Ang-(1-7) can restore this early $\beta$ cell dysfunction associated with calcium levels. Our previous study showed that ACE2 knockout mice exhibited progressive impairments in glucose tolerance and reduced first-phase insulin secretion (14); thus, in vivo and in vitro experiments were consistent. These results demonstrated the importance of the ACE2-Ang (1-7)-Mas axis in the early stages of diabetes and its protective role in the early treatment of diabetes, as well as the correlation with Ang (1-7) and oxidative stress in INS-1 cells.

Islet $\beta$ cells detect changes in blood glucose and maintain glucose homeostasis. The mitochondrial energy metabolism conditions in pancreatic $\beta$ cells are crucial for the capacity of sensing blood glucose levels (28). The importance of mitochondria in type 2 diabetes has been demonstrated by the identification of causal mutations in the mitochondrial DNA in pancreatic $\beta$ cells $(29,30)$. Excessive AngII can increase mitochondrial ROS production, and reduce the mitochondrial membrane potential and respiratory control ratio (21). Recent studies have shown that AT1R blockers can protect the mitochondria in the kidney in a type 1 diabetes mouse model. In the present study, Ang (1-7) restored the impaired MMP and exhibited protective effects on mitochondrial function. The protective effect on mitochondrial function is likely to be one of the mechanisms underlying the antioxidant effect of Ang (1-7) in pancreatic $\beta$ cells.

In conclusion, to the best of our knowledge, the present study was the first to demonstrate the antioxidant effect of Ang (1-7) in the INS-1 pancreatic cell line and the restorative effects of Ang (1-7) on insulin secretion. This was associated with restoration of calcium signaling, reduction of ROS generation and restoration of the impaired mitochondrial function in oxidative stress conditions. The effects observed following treatment with Ang (1-7) were inhibited by its specific antagonist, A779. This study demonstrated that reducing ROS production and restoring mitochondrial function are likely to be the mechanisms underlying the protective effects of Ang (1-7) on pancreatic $\beta$ cell function under oxidative stress. Notably, this experiment confirms the importance of Ang (1-7) in the early stages of diabetes. These findings may assist with the treatment of diabetes in future, potentially during the development of novel therapeutic strategies.

\section{Acknowledgements}

The present study was supported by the National Natural Science Foundation of China (grant nos. 81070644, 30871187 and 30671001).

\section{References}

1. Lau T, Carlsson PO and Leung PS: Evidence for a local angiotensin-generating system and dose-dependent inhibition of glucose-stimulated insulin release by angiotensin II in isolated pancreatic islets. Diabetologia 47: 240-248, 2004.

2. Favre GA, Esnault VL and Van Obberghen E: Modulation of glucose metabolism by the renin-angiotensin-aldosterone system. Am J Physiol Endocrinol Metab 308: E435-E449, 2015 .
3. Ko SH, Kwon HS, Kim SR, Moon SD, Ahn YB, Song KH, Son HS, Cha BY, Lee KW, Son HY, et al: Ramipril treatment suppresses islet fibrosis in otsuka long-evans tokushima fatty rats. Biochem Biophys Res Commun 316: 114-122, 2004

4. Nakayama M, Inoguchi T, Sonta T, Maeda Y, Sasaki S, Sawada F, Tsubouchi H, Sonoda N, Kobayashi K, Sumimoto H and Nawata H: Increased expression of NAD (P)H oxidase in islets of animal models of Type 2 diabetes and its improvement by an AT1 receptor antagonist. Biochem Biophys Res Commun 332: 927-933, 2005.

5. Tikellis C, Wookey PJ, Candido R, Andrikopoulos S, Thomas MC and Cooper ME: Improved islet morphology after blockade of the renin-angiotensin system in the ZDF rat. Diabetes 53: 989-997, 2004.

6. Cheng Q, Law PK, de Gasparo $M$ and Leung PS: Combination of the dipeptidyl peptidase IV inhibitor LAF237 [(S)-1-[(3-hydroxy-1-adamantyl)ammo]acetyl-2-cyanopyrrolidine] with the angiotensin II type 1 receptor antagonist valsartan [N-(1-oxopentyl)-N-[[2'-(1H-tetrazol-5-yl)-[1,1'-biphenyl]-4-yl] methyl]-L-valine] enhances pancreatic islet morphology and function in a mouse model of type 2 diabetes. J Pharmacol Exp Ther 327: 683-691, 2008.

7. Frantz ED, Crespo-Mascarenhas C, Barreto-Vianna AR, Aguila MB and Mandarim-de-Lacerda CA: Renin-angiotensin system blockers protect pancreatic islets against diet-induced obesity and insulin resistance in mice. PLoS One 8: e67192, 2013.

8. Braga MF and Leiter LA: Role of renin-angiotensin system blockade in patients with diabetes mellitus. Am J Cardiol 104: 835-839, 2009.

9. Scheen AJ: Renin-angiotensin system inhibition prevents type 2 diabetes mellitus. Part 1. A meta-analysis of randomised clinical trials. Diabetes Metab 30: 487-496, 2004.

10. Scheen AJ: Renin-angiotensin system inhibition prevents type 2 diabetes mellitus. Part 2. Overview of physiological and biochemical mechanisms. Diabetes Metab 30: 498-505, 2004.

11. Califf RM, Boolell M, Haffner SM, Bethel M, McMurray J, Duggal A and Holman RR; NAVIGATOR Study Group: Prevention of diabetes and cardiovascular disease in patients with impaired glucose tolerance: Rationale and design of the nateglinide and valsartan in impaired glucose tolerance outcomes research (NAVIGATOR) Trial. Am Heart J 156: 623-632, 2008.

12. Yang JK, Feng Y, Yuan MY, Yuan SY, Fu HJ, Wu BY, Sun GZ, Yang GR, Zhang XL, Wang L, et al: Plasma glucose levels and diabetes are independent predictors for mortality and morbidity in patients with SARS. Diabet Med 23: 623-628, 2006.

13. Li W, Moore MJ, Vasilieva N, Sui J, Wong SK, Berne MA, Somasundaran M, Sullivan JL, Luzuriaga K, Greenough TC, et al: Angiotensin-converting enzyme 2 is a functional receptor for the SARS coronavirus. Nature 426: 450-454, 2003.

14. Niu MJ, Yang JK, Lin SS, Ji XJ and Guo LM: Loss of angiotensin-converting enzyme 2 leads to impaired glucose homeostasis in mice. Endocrine 34: 56-61, 2008.

15. Bindom SM, Hans CP, Xia H, Boulares AH and Lazartigues E: Angiotensin I-converting enzyme type 2 (ACE2) gene therapy improves glycemic control in diabetic mice. Diabetes 59: 2540-2548, 2010.

16. Benter IF, Yousif MH, Cojocel C, Al-Maghrebi M and Diz DI: Angiotensin-(1-7) prevents diabetes-induced cardiovascular dysfunction. Am J Physiol Heart Circ Physiol 292: H666-H672, 2007.

17. Xia H, Suda S, Bindom S, Feng Y, Gurley SB, Seth D, Navar LG and Lazartigues E: ACE2-mediated reduction of oxidative stress in the central nervous system is associated with improvement of autonomic function. PLoS One 6: e22682, 2011.

18. Dhaunsi GS, Yousif MH, Akhtar S, Chappell MC, Diz DI and Benter IF: Angiotensin-(1-7) prevents diabetes-induced attenuation in PPAR-gamma and catalase activities. Eur J Pharmacol 638: 108-114, 2010.

19. Xue B,Zhang Z, Beltz TG, Guo F, Hay M and Johnson AK: Estrogen regulation of the brain renin-angiotensin system in protection against angiotensin II-induced sensitization of hypertension. Am J Physiol Heart Circ Physiol 307: H191-H198, 2014.

20. Drews G, Krippeit-Drews P and Düfer M: Oxidative stress and beta-cell dysfunction. Pflugers Arch 460: 703-718, 2010.

21. Dikalov SI and Nazarewicz RR: Angiotensin II-induced production of mitochondrial reactive oxygen species: Potential mechanisms and relevance for cardiovascular disease. Antioxid Redox Signal 19: 1085-1094, 2013.

22. Pi J, Bai Y, Zhang Q, Wong V, Floering LM, Daniel K, Reece JM, Deeney JT, Andersen ME, Corkey BE and Collins S: Reactive oxygen species as a signal in glucose-stimulated insulin secretion. Diabetes 56: 1783-1791, 2007. 
23. Robertson RP: Chronic oxidative stress as a central mechanism for glucose toxicity in pancreatic islet beta cells in diabetes. J Biol Chem 279: 42351-42354, 2004.

24. Giani JF, Mayer MA, Muñoz MC, Silberman EA, Höcht C, Taira CA, Gironacci MM, Turyn D and Dominici FP: Chronic infusion of angiotensin-(1-7) improves insulin resistance and hypertension induced by a high-fructose diet in rats. Am J Physiol Endocrinol Metab 296: E262-E271, 2009.

25. Santos SH, Fernandes LR, Mario EG, Ferreira AV, Pôrto LC, Alvarez-Leite JI, Botion LM, Bader M, Alenina $\mathrm{N}$ and Santos RA: Mas deficiency in FVB/N mice produces marked changes in lipid and glycemic metabolism. Diabetes 57: 340-347, 2008.

26. Satin LS: Localized calcium influx in pancreatic beta-cells: Its significance for $\mathrm{Ca}^{2+}$-dependent insulin secretion from the islets of Langerhans. Endocrine 13: 251-262, 2000.
27. Carter JD, Dula SB, Corbin KL, Wu R and Nunemaker CS: A practical guide to rodent islet isolation and assessment. Biol Proced Online 11: 3-31, 2009.

28. Matschinsky FM, Magnuson MA, Zelent D, Jetton TL, Doliba N, Han Y, Taub R and Grimsby J: The network of glucokinase-expressing cells in glucose homeostasis and the potential of glucokinase activators for diabetes therapy. Diabetes 55: 1-12, 2006

29. Silva JP, Köhler M, Graff C, Oldfors A, Magnuson MA, Berggren PO and Larsson NG: Impaired insulin secretion and beta-cell loss in tissue-specific knockout mice with mitochondrial diabetes. Nat Genet 26: 336-340, 2000.

30. Maassen JA, 'T Hart LM, Van Essen E, Heine RJ, Nijpels G, Jahangir Tafrechi RS, Raap AK, Janssen GM and Lemkes HH: Mitochondrial diabetes: Molecular mechanisms and clinical presentation. Diabetes 53 (Suppl 1): S103-S109, 2004. 